\title{
Yunus Emre Düşüncesinde Bir Eğitim Modeli Olarak “ínsân-ı Kâmil”: Konuya Öğretim Programlarının Kültürel ve Felsefi Temelleri Bağlamında Bir Yaklaşım
}

\author{
"Al-Insān al-Kāmil" as an Education Model in Yunus Emre Ideology: An Approach \\ Based on Cultural and Philosophical Bases of Education Programmes
}

\section{Doç. Dr. Mizrap Polat}

\section{Öz}

Yunus Emre Anadolu İslam coğrafyasının önemli bir edebiyat, tasavvuf ve düşünce adamıdır. Yunus’un Eğgitim Biliminin hem kuram hem de uygulama alaninda kadim bir tasavvuru olan "İnsân-ı Kâmil" düşüncesi bağlamında değerlendirilebilecek yaklaşımlarının, günümüz okul ögretim programlarına yansıma durumu bu makalenin ana konusudur. Bu bağlamda bir yandan Yunus Emrénin eserleri, diğer yandan ise Ortaöğretim Felsefe Dersi Programı ele alını hem içerik hem de eğitim bilimi bakış acısından analiz edilmiştir. Araştırmamızda elde edilen sonuç ise, medeniyetimize özgü bir eğitim-öğretim konsepti olan "İnsân-ı Kâmil" tasavvurunun günümüz eğitim kuram ve uygulamasina yeterince yansımadığıdır. İnsân-ı Kâmil, mükemmel, yetkin ve olgun insan olma sürecine bilinçli olarak girmiş, değerlerin taşıyıcısı ve rol model olma vasfina sahip bir insanı ifade eder. Dolayısıyla bu kavram değer öğretimi yönünden de oldukça önemlidir. Klasik eğitim düşüncesinin temel kavramlarının Eğitim Biliminin günümüzde sunduğu bilgi ve tecrübeleri ışı̆̆ında yaptcı bir eleştiriye tabi tutularak yeniden okunması ülkemizdeki eğitim kuram ve uygulamasının özgünleşerek gelişmesine katkı sunması beklenen bir durumdur.

Anahtar Kelimeler: Felsefe Dersi Öğretim Programları, Değer Öğretimi, Yunus Emre, İnsân-ı Kâmil Eğitim Modeli

\begin{abstract}
Yunus Emre is an important figure in Islamic Anatolian geography in terms of literature, sufism and thoughts. The main subject of this study is the reflection of approaches that could be interpreted within the context of "al-Insān al-Kämil" ideology of Yunus which is a classical concept in both theoretical and application field of Educational Sciences to current school curricula. Within this purpose, the programme of Secondary School Philosophy lessons have been selected and analysed as a sample. The obtained result is that the education and training concept of "Al-Insān al-Kämil" which is exclusive to our civilization is not sufficiently redounded on modern-day education theories and applications. AlInsān al-Kämil represents an individual who consciously set off for being a perfect, competent, and dignified human and who has the required attributes for being a conductor of values and a role model and therefore, is of much importance for teaching values. It is an anticipated issue for education theories and applications to be developed by being genuine that the basic concepts of classical education ideology are examined again with constructive criticism through the knowledge and experiences of modern-day Education Science.
\end{abstract}

Keywords: Philosophy Lesson Education Programmes, Values Teaching, Yunus Emre, al-Insān al-Kāmil Education Model

Doç. Dr. Mizrap Polat, Eskişehir Osmangazi Üniversitesi Eğitim Fakültesi, mpolat@ogu.edu.tr 


\section{Giriş}

$\mathrm{Bu}$ makale İslam Eğitim Düşüncesine özgü olan "İnsân-1 Kâmil" modelinin Yunus Emre’nin (doğumu 1240-1, ölümü 1320-1) düşünce dünyasına yans1malarını onun eserlerini inceleyerek ortaya koymayı hedeflemektedir. Bu amaçla Yunus Emre'nin "Divan" (Tatc1, 2005) ve "Risalet'un-Nushiyye" (2012) isimli eserleri hem felsefi hem de eğitim bilimleri bakış ac1sından analiz edilmiștir. Müteakiben Yunus Emre’nin "İnsân-1 Kâmil" eğitim modeli dairesinde yorumlanabilecek nazım ve nesir halinde dillendirilen görüşlerinin lise müfredatı içinde kendine yer bulan Felsefe Dersinin öğretim programında konu edinilip edinilmediği hususu ilgili programın incelenmesiyle ortaya konulup elde edilen veriler hem eğitim felsefesi hem de öğretim bilimi (didaktik) zaviyesinden analiz edilerek tartışılmaya çalışılmıştır. Yunus'un anılan bu eğitim düşüncesinin lisede okutulan Felsefe Dersi Kitabına nasıl yansıdığı hususu da adı geçen kitabın içerik ve didaktiksel analiziyle netliğe kavuşturulup tartışılmıştır. Bu tartışmalar öğretim programlarının kültürel, felsefi ve tarihi arka planının neler olması hususunu da kapsayacak şekilde genişletilmiştir. Makalenin konusu ve araştırma metoduyla ilgi bu kısa bahisten sonra Yunus'un yaşadığ dönemin siyasi, kültürel ve sosyal şartlarına ve bu şartların onun düşüncesine muhtemel etkilerine kısaca değinmenin isabetli olacağ 1 kanaatindeyiz.

Mevlana (1207-1273), Hacı Bektaş (1209-1270) ve Yunus'un yaşadığı 13. yüzyıl Anadolu'da devlet otoritesinin halk üzerinde zayıf olduğu bir dönemdi. Anadolu’da hüküm süren Haçlı ve Moğol istilalar1nın yanında Beylikler ve Anadolu Selçuklu devleti arasında da iktidar savaşları mevcudiyetini korumaktaydı. Tüm bu baskılar nedeniyle Selçuklu Devleti fiilen dağılmış durumdaydı (Gordlevski, 1988, 62 vd.). Siyasi otorite boşluğunun olduğu dönemler küçümsenmeyecek derecede aklın ve irfanın özgürleştiği, resmi, ısmarlama ve dizayn edilmiş bilgi ve fikrin oluşma imkânının zayıfladı̆̆ 1 dönemlerdir. 13. yüzyılda Anadolu'da önemli bir Hristiyan nüfusu mevcuttu (Şeker, 2002, 59 vd.). Müslüman ve Müslüman olmayan unsurların Anadolu'daki birlikte mevcudiyeti bir yandan kültürlerin etkileşimini, diğer yandan ise rekabetini beraberinde getirmekteydi. Bahsi geçen yüzyllda Anadolu'daki mevcut dinler ve mezhepler kendilerini temsil eden önder şahsiyetler üzerinden temsil edilme, etkinlik ve kabul görme rekabetine girmişlerdi. Kendini halkın üzerinde ve özel bir konumda gören hiyerarşik olarak organize olmuş ve siyasileşmiş kilise Hıristiyanlığı, ruhban sınıfı olmayan, kendini din adına resmi kuruma karşı bağımlı ve sorumlu hissetmeyen Mevlana, Hacı Bektaş Veli, Yunus Emre gibi halk önderleri ve gayri resmi (enformel) toplum eğiticileriyle rekabet halinde idi. Anadolu'daki Hristiyan kiliseleri o zamanki sivil toplum kuruluşları olan dergâhlarda halk içinde konumlanmış Yunus Emre gibi Müslüman toplum eğiticileri karşısında zorlanmaktaydı. Bu önder eğiticiler toplumun her kesimini kuşatıcı insan sevgisi gibi evrensel fikirlerle, tekkelerde kurdukları aşevleriyle yoksula yemek sunmak gibi insani olan ve günlük yaşam bağlamında toplumla sosyal dayanışmayı önceleyen fiiliyatlarıyla, kısacası değer üreten fikirleri ve değer yaşatan eylemleriyle öne çıkmışlardı (Çetin, 1981, s. $135 \mathrm{vd}$.). Bu faaliyetler yaşatarak eğitmenin ve yaşam içinde öğrenmenin Anadolu'daki önemli örnekleri olarak kabul edilebilir.

Selçuklu ve Bizans komşu devletleri arasındaki askeri rekabetin 13. yüzyıl sonlarında zayıflaması bu iki devletin temsil ettiği kültürler arasında marifetin ve hikmetin rekabetine saha açmıştı. Kültürlerin ve medeniyetlerin şiddet içermeyen rekabeti onların yapıcı etkileşmelerine ve bu vesileyle de evrensel karakterlerini güçlendirmelerine çoğu kez kapı açmıştır. İlanihaye diyebiliriz ki, 13. yüzyılda Anadolu'daki siyasi zafiyet ve otorite boşluğu düşünce zenginliğinin ve özürlügünün zemin bulmasına ortam hazırlamıştı. Âlimler ve ariflerin (tasavvuf önderlerinin), halkın vicdanı, bilgi ve irfanın özgür sözcüleri olduğu, birçok dinin ve kültürün aynı coğrafi mekanda karşılaştığı ve hatta karşı karşıya durduğu dönemler, yani kiriz, teyakkuz ve rekabet dönemleri büyük düşünce akımlarını ve düşünce önderlerini doğurmaya müsait dönemlerdir. Bu dönemde Anadolu'daki İslam düşünürlerinin ilgi alanını dini bilimlerin yanında ahlak, bilgi (epistemoloji), eğitim ve insan felsefesi (antropolojik felsefe) oluşturmaktaydı. Adı geçen bilim dalları ve alt dallarının kesiştiği kavşak ise o dönemde Anadolu'da revaçta olan Tasavvuf Felsefesiydi. Yunus Emre gibi 13. yüzyıl Anadolu İslam düşünürlerinde sadece kuramsal felsefe gözlenmez, onlar bilginin, inancın ve aklın insanı erdemli kılmasını ve bu erdemin yaşama yansımasını sıkça vurgularlar. Bu düşünürler özellikle değer felsefesi ile ilgili düşüncelerinin bizatihi rol modelleri olmuş, onları yaşamış ve ayrıca onların öğretilmelerine hem tekkelerindeki derslerinde, hem eserlerinde ve hem de yaptıkları 
öğrenme ve öğretme amaçlı seyahatlerinde çaba sarf etmişlerdir. Bu bağlamda onların felsefesi öncelikle kendilerinin tatbik ettiği ve toplumun yaşamında yansımaları olan pratik felsefe özelliğine de sahiptir. Tatbikat alanı oluşturmayı hedefleyen bir felsefe ise doğrudan eğitimi önceleyen ve hedefleyen bir felsefe niteliğindedir zaten. Çünkü eğitim fertte ve toplumda istenilen olumlu gelişmeyi hedefler. Hem Hacı Bektaş Veli, hem Mevlana ve hem de Yunus Emre düşüncelerinin eksenine insanın ahlakileşmesini, bilgeleşmesini ve alemdeki (evrendeki) konumunu bilmesini koymuşlardır ve anlatımlarını sadece felsefe nazariyesi diliyle değil, aynı zamanda nazım (şiir) ve tahkiye (hikayelerle anlatım) diliyle hem yüksek eğitimli kesime, hem de geniş halk tabakalarına ulaştırmayı amaçlamışlardır. Mesela Mevla’nın Rubaileriyle daha çok entelektüel kesimi muhatap alırken, Mesnevisindeki (Mevlâna Celâleddin Rûmî, 2011) hikayeleriyle de halka da hitabı da ihmal etmez. Yunus'un şiiri de sanat için bir sanat değil halka ulaşıp eğitmek için bir araçtır.

Yunus Emre'yi muasırı olan Mevlana'dan, Hacı Bektaş Veliden ve diğer Anadolu toplum önderlerinden ayrı düşünmek zordur. Yunus kendisi genelde Anadolu içinde kalmış bir bilge olmasına rağmen, coğrafi ve kültürel sınırları aşan Nişabur'lu Hacı Bektaş’tan ve Belh'li Mevlana'dan oldukça etkilenmiştir. Özellikle Hacı Bektaş Veli'nin Makâlât isimli eseriyle Yunus Emrenin Risâletü’n-Nushiyye'si içerik bakımdan da benzerlikler taşır. Mesela bu iki eserde de insan nefsinin çeşitli karakterleri dört unsurun (toprak, ateş, yel ve su) sifatlarıyla sembolleştirilerek anlatılır. (Hacı Bektaş Veli 2007, s. 43 vd. [2a vd.]; Yunus Emre 2012, s. 7 vd.). Ayrıca Hacı Bektaş Veli'nin Makâlât'ında (2007) bahsettiği 4 kapı 40 makam Ahmet Yesevi’nin Fakrnamesinde de (2016) konu edilmiştir. Bu bağlamda diyebiliriz ki, Yunus sadece Anadolu'dan değil tüm İslam Dünyasının tasavvuf kaynaklarından silsile yoluyla beslenmiştir. Yunus'un özellikle Risâletü̉nNushiyye'de (2012) gözlenen felsefi ve kelâmi derinlik, onun ciddiye alınması gereken bir tahsil gördüğüne ve kendisinin yetiștiği Taptuk Emre Dergahında Arap ve Fars kaynaklarına da dayanan kayda değer bir öğretimin mevcudiyetine işaret eder. Bu da, dergâhların o yüzyılda da sadece bir tezkiye ve tefekkür mekânı değil, aynı zamanda bir ilim evi olduğunu da bize göstermektedir.

\section{Yunus Emre'nin İnsan Algısına Umumi Bir Bakış}

Immanuel Kant, bizzat kendisi amaç alan ve diğer bir amaca araç kılınamayan değeri, dokunulmaz mutlak değer olarak tarif eder. Bu değeri de, sadece akıllı varlığa, yani insana has olarak gördüğ̈ "onur"la (Würde) özdeşleştirir (Kant, 1786: 64-80). Onur denilen değeri tüm varlıkların kendi tabiatlarına uygun olarak bozulmadan var olma hakkına teşmil etmemiz gerekir. Bugünkü küresel iklim ve çevre sorunlarını dikkate aldığımızda çevreyi korumanın aslında varlığın onurunu korumak anlamına geldiğini de görürüz. İnsan onurunun içinde yaşadığı dünyanın yaşanılabilir halde kalmasıyla ilişkili olduğu ahlaki ve tabii bilimlerle sabit kılınmıștır. Bu vecihle sadece insan onurundan bahsetmek yerine varlığın ortak onurundan bahsetmeliyiz. Böylelikle insan merkezli değer düşüncesinden varlık merkezli değer düşüncesine doğru bir açılım olabilir. Yunus gibi mutasavvıfların ve mürebbilerin varlığın birliğinden, yani "vahdet- $i$ vücuttan", ki buna "vahdet-i mevcudat" da diyebiliriz, bahsetmeleri varlığın uluhiyette Allah'la bir olması anlamına gelmediği, bunun daha çok, varlığın birbirinden ayrılmaz bir onura ve bu onurun da varllğ 1 yaratmakla onurlandıran Allah’a dayandığı anlamına geldiği görüşündeyiz. Tabii ki, bu varlık âleminde kabiliyetlerinden dolayı sorumluluğu da yüksek olan insan çok daha önemli bir konumdadır. Bu nedenle yukarıda da kısaca değinildiği gibi insan olmak başlı başına bir değerdir.

Yunus'ta insan sevgisi hümanistlerin çoğunda olduğu gibi Allah'a rağmen değil O’ndan dolayıdır. Dolayısıyla Yunus Emre'deki “Yaratılanı hoş gör Yaratandan ötürü" şeklinde öz ifadesini bulan insana değer atfetmeyi Batı düşünce geleneğinin bir kavramı olan "hümanistlikle" tarif etmek hem yanlış hem de anakronist bir yaklaşımdır. Bu bağlamda Talat Sait Halman'ın Yunus'u göreceli ve kayıtlı bile olsa (Halman, 1991, s. 162 vd.) hümanist olarak tarif etmesi kanaatimizce Yunus'u toptancı bir anlayışla kavrama yanlışına götürebilir. Yunus'un insan sevgisi "sevgi de nefret de Allah içindir" mealinde öz olarak ifadesini bulan hadis mucibincedir (İbni Hanbel 3/430, 3/440, 4/286). O insanı yaratılışta değerli bir varlık olarak severken, kibirli, cimri ve koğucu insanı da şiddetle yermiştir (Yunus Emre 2012). Yunus insanı mutlak kutsiyet sahibi ve alemin efendisi olarak görmez, 
fakat insanın kemalet sürecine girerek yaratılışının amacını (emaneti) yerine getirebileceğini savunur ve onu bu yönüyle önemser ve saygıyla karşılar. Batı hümanizmi hiç bir şekilde insanı Allah’n yeryüzündeki halifesi olarak sunan insan anlayışıyla bağdaşmaz. Örneğin Yunus Emre’nin kamil insan anlayışı Nietzsche'nin "insanüstü insan" (Übermensch) anlayışından farklıdır. Nietzsche'nin adı geçen insan tiplemesi, inancı bir zafiyet olarak gören, ahlaki ilkelerin insanın muhtariyetini kısıtladığına inan ve bu nedenle de onları tanımayan ve günümüz insanın üzerinde bir kabiliyete sahip olması düşünülen bir insan idealidir (Nietzsche, 2012, s. 366 vd.). Halbuki Yunus’a göre insan her şeyin merkezi değil emanetin taşıyıcısı ve varlığa karşı sorumlu olandır. İnsan en güzel yaratılışta yaratılmasına rağmen, varlığın en ednası olma riskini taşıyan da bir varlıktır (Kuran-1 Kerim, 95: 4-6). Alçaltıcı (edna) duruma düşmekten insanı korumak için diğer halk eğiticileri gibi Yunus ta gerekli uyarıları yapmış ve bu amaçla Risâletü’n-Nushiyye’sini (2012), yani “Nasihatler Risalesini” yazmıştır.

Yunus'un insanı 'insanlık' için insandır. Allah’ın yeryüzündeki halifesi olan bu insan, Allah adına yetki kullanmaya kalkışan değil, yetki istemeden sorumluluk alan varlıktır. O tüm varlığa karşı ihsan, ikrar, takva ve tevazu değerleri mucibince hareket edendir. Şeytanın tavrı Kuran'da (2: 30 vd.) tevazuyu terk edip kibri tercih ettiğinden yerilir. Yunus tevazuyu ve toplumun sosyal bakımdan zayıf kesimleriyle dayanışma içinde olmayı erdemleşme ve bilgeleşme yolunun önemli bir değeri ve hedefi olarak tarif ederek, bu değeri kendi eğitim modelinin önemli bir kazanımı olarak sunar. Yunus'un aşağıdaki dizesini bu anlamda okumak mümkündür (Tatc1, 2005, s. 28 [11]):

Ol kişi kim yol eridür garîb gönüller yâridür

\section{Bir Değer Taşıyıcısı Olarak İnsân-ı Kâmil ve Bunun Yunus Emre'nin Düşünce Dünyasındaki Tezahürü}

İnsân-1 Kâmil (Nesefî, 2013; Cebecioğlu 2014, s. 243 vd.) bir ıstılah olarak öncelikle Tasavvufa ait bir kavram gibi görünse de, bu kavramı geniş anlamıyla bir eğitim tasavvuru olarak anlamamız gerekir. Medeniyetin insan unsurunun ilmi, irfanı ve ahlaki boyutlarıyla gelişim ve olgunlaşma süreç ve hedefinin tarifine mündemiç olan bu tasavvur, İslam’ın kendine has ve özgün bir eğitim nazariyesini ve uygulamasını ifade eder. Bu isim tamlaması kendisini oluşturan iki kelimenin anlam bütünlüğünü tam manasıyla yansitır: Bu iki kelime insan ve kemalettir. İnsan olmak başlı başına ontolojik, yani mevcudiyete ait bir değerdir, kamillik, kemaleti, diğer bir deyimle olgunluk ve yetkinliği daimi bir sıfat olarak taşımayı ifade eden bir erdemi (fazileti) beyan eder. İnsan olmak değer silsilesinin başında gelir. Adalet, barış, dayanışma gibi diğer değerler de zaten insan onurunu muhafaza eden koruyucu değer mesabesindedirler. Kendisi başlı başına bir değer olan bu insanın kabiliyetlerini geliştirip kullanarak yetkinleşmesi, ahlakileşmesi ve bilgeleşmesi gerekmektedir. Bu gerekliliği yerine getirme eğitim ve öğretimin asli hedefidir. İnsan-1 Kâmil eğitim modelinin önemli bir kavramı olan "ariflik"in tanıyarak, anlayarak, inanarak ve hissederek bilmek anlamını da içerir. Bu bağlamda bilgi bir makam ve metaa sahip olmak için değil, hikmet ve irfan (Cebecioğlu, 2014, s. 216 vd., 245) ehli olmak için amaçlanır. Bu irfan ve hikmet ehli insan yeryüzünün efendisi değil, yeryüzündeki ahengin kilit taşı ve ictimai ve terbiyevi olarak da rol model olma sıfatını taşıyan bir şahsiyettir. Bu çerçevede erdemli toplumu, ahlak ve ilim yolunda kendini kemalete ulaştıran fertlerin örnek alındığı toplum diye tarif etmemiz mümkündür. Buradan hareketle diyebiliriz ki, "Kamil İnsan" tasavvuru Platon (tarihsiz) ve Farabi (2001) gibi düşünürlerde görülen erdemli toplum düşüncesinin bir anlamda fert bağlamında karşılığını ifade eder. Fakat bu insan hayali bir insan değil olması mümkün olan bir insandır.

Bir çok kimse İnsan-1 Kâmil'den kemalette son noktaya ulaşmışlı̆̆ı, yani İnsan- $\imath$ Ekmel'i anlasa da (Cürcânî 2014, s. 86) kanaatimizce bu pek de doğru değildir. Burada geçen "kâmil" sıfatı kemalette en üst noktaya ulaşmış insanı tasvir etmez. Bu sıfat olgunlaşma ve yetkinleşme sürecine girmiş insanı ifade eder. Eğer böyle olsaydı bu eğitim modeli bir ideal belki de bir ütopya anlamına gelirdi. Zaten İnsân-1 Kâmil (alinsân al-kâmil) kavramıyla İnsân-1 Ekmel ("al-insân al-akmal"), yani olgunlukta daha da ileri gidilemez en yüce noktaya ulaşmış bir insan kastedilmemiştir düşüncesindeyiz. Kuran’da insan aşağıların en aşağısı (esfele safilin) ile en güzel yaratılma vasfının (ahsen-i takvim) gereğini yerine getirme yetkinliği arasındaki süreci yaşayan varlık olarak görülür (Kuran, 95: 4-6). İnsân-1 Kâmil' de bu anlamda kendini bilge kılma ve kişiliğini geliştirme sürecine giren ve bunu ömür boyu yaşayan şahsı tarif eder. Tasavvuf bu nedenle 
kamil insan olma sürecine yol, yani tarik (tarikat) adını vermiştir. Bu süreç öz eleştiri yapabilen, yani nefs-i levvâme (İmam Gazali, 2004, s. 43) kademesine ulaşan bir şahsiyet kazanma konumuna gelmekle başlar ve ilerler. Yunus Emre der ki (Yunus Emre, 2012, s. 26):

\section{Kogıl ayruk sözi, sen seni gözle \\ Senin sucmula sen seni yüzle}

Yunus Emre, insanın alemdeki yerini, Allah'a olan yakınlığını ve O’nun katındaki değerini aşağıdaki dizeleriyle tasvir eder (Yağmur, 2013, s. 47). Bu değer tespiti bir yandan da yaratılışla Allah'a ve itaatte ise Kuran’a bağlılıkla anlamlandırılmaktadır.

\section{Benem ol aşk bahrisi denizler hayrandır bana \\ Derya benim katremdir zerreler umman bana}

\section{Kafdağı zerrem değil ay u güneş kul bana \\ Hak'tır aslım şek değil mürşittir Kuran bana}

Yukardaki dizelerde ifadesini bulan bu kendi öz şahsında insan olmayı keşfediş, aynı zamanda kendini bilme ve tanıyabilme sürecine girmeyi, yani marifetin başlangıcını yakalamayı ifade eder. İnsanın kendini bilmesi ve tanıması onun zaaflarını yenip, yeteneklerini de geliştirerek daha iyi olma, yani kamil insan olma sürecine girme azminin başlangıç noktasıdır. Dış dünyadan (afaktan) okuma ve gözlem yoluyla edinilen bilgi ve tecrübe insanın kendi içinde (derununda) yaptığı yolculukla birleșip fazilet yükleyen bilgiye dönüşmüyorsa yetersizdir görüşü mutasavvıflarda hakim bir görüştür. Onlar ayrıca afakî, bir başka deyimle fiziki uğraşların ve coğrafi yolculuğun kişide enfüsi ve deruni (içsel) yolculuğu ve değişimi de tetiklemesini ister. Bilginin derunileştirilmesi (içselleşmesi) bir anlamıyla insanın kendini keşfetmesini ve alemdeki yerini bilmesini (İhvân-1 Safâ, 2013, s. 319 vd.), diğer yandan da bilgiyi faziletle, diğer bir deyimle değerle birleştirmesini ifade eder. Değerler kural koyan, nitelik kazandıran, duruş ifade eden düşünce, niyet, isteklendirme ve duygulardır, ki onlar eylemlerin derunlarını, onların arkasındaki manayı ve fikri cevheri ifade ederler. Yunus insanın kendini bilgi, hikmet ve faziletle yapılandırma sürecinde yalnız kalmaması için, gönül sarayını temiz tutup orada Allah’ mukim kılması gerektiğini vurgular (Yunus Emre 2012, s. 116):
Kaçan dost gele deyu hazır olgıl

Sarayunı düzeltgil hazır olgıl

Yunus Emre insanın kendi kendinin mürebbisi (öğretmeni) ve murakıbı (denetçisi ve gözetleyicisi) olması gerektiğini ifade etmek suretiyle eğitimde öğrenenin muhtariyetine önem atfeder. Şahsın muhtariyetini esas alan eğitim insanın nesne değil özne olduğunu, eğitimin ise kendini inşa eden insana müdahaleden ziyade, ona yol göstermek anlamına geldiğini beyan eder. Bu manada kamil insan, kendini sürekli eğitebilme kabiliyetine kavuşan ve öz mesuliyetini eline almış insan demektir. Bu insan kendine önem veren, anlam yükleyen ama bunu yaparken de kibre (Yunus Emre, 2012, s. 70 vd.) bulaşmayan insandır. İnsanı çok yönlü olgunluğa ulaştırmak isteyen İnsân-1 Kâmil eğitim modeli bilgi ve eylem merkezli ve aynı zamanda da ahlak yönelimli bir eğitimdir. Çünkü burada insan bildiğinin ve öğrenebildiğinin daha fazlasıdır. Bu bağlamda eğitim ve öğretim ontolojik olarak şerefli olan insanı bilgi, beceri, yetenek ve ahlak bakımından etkin hale getirmektir, yani bir nevi insanda mündemiç (saklı) olanı ayan (görünür) kılmaktır. Tüketim ve lüks toplumunda ise insan bildiği, yapabildiği ve alabildiği kadar önemlidir. Günümüz dünyasına hakim eğitim ve öğretim anlayışı da kazanımlarını bu tüketim toplumunun beklentileri üzerine kurgulamış gözükmektedir.

Yunus Emre insan haklarına saygıyı sadece hukuki bağlamda bir saygı olarak anlamaz, o bu saygiya iman, ibadet ve ahlak boyutunu da katar. O insanı Hakkın aynası ve insanın kalbini de Hakkın mekânı olarak görür (Tatc1, 2005, s. 326 [339]). Yunus'un aşağıdaki dizelerinde Allah'ın rızasını kazanmak ile insan haklarına (kul hakkına) riayet arasındaki doğru orantılı münasebetin mevcudiyetine dikkat çekilir. Böylelikle Allah’n sevgisini kazanmanın Allah'in yer yüzündeki halifesi olan insanın (Kuran, 2: $30 \mathrm{vd}$.) gönlünü kazanmakla mümkün olduğu ifade edilerek, bir anlamda insan onuruna en üst seviyeden vurgu yapılmış olunur. Neticede Yunus'un sadece insan merkezli bir eğitimin yetmeyeceğini, eğitimin insaniyet merkezli ve tüm varlık açılımlı olması gerektiğini önemsediğini söyleyebiliriz. Oun aşağıdaki dizelerini bu anlamda tefsir etmemiz mümkündür (Tatc1, 2005, s. $163[166])$ : 
Bir kez gönül yıkdunısa bu kıldugin namâz degül

Yetmiş iki millet dahi elin yüzin yumaz degül

Yunus Emre ibadetin içselleştirilmesini ve bunun da ilişkileri ve eylemleri ahlakileştirmesini, yani ibadetin salih amele zemin hazırlamasını din eğitim ve öğretiminin hedefi olarak görür. Yunus, kamil insan olma azminde olan insanın âbid olmasının yetmeyeceğini, onun arınma çabasını devam ettirme, ahlakî ve irfanî olgunluğa ulaşma gayretini sürdürmesi gerektiğini beyan eder. Yunus'un bu yaklaşımı onun bilgi merkezli bir din eğitiminin yeterli olamayacağı, din eğitiminin şahsiyet, maneviyat ve duygu eğitimini de içine alması gerektiği gerçeğini yüzyıllar öncesinden kavradığının bir göstergesidir. Yunus der ki (Tatcı 2005, s. $39[24])$ :

Bir tona kan bulaşıcak yumayınca mismil olmaz Gönül pâsı yunmayınca namâz edâ olmayısar Gönül pâsın yudunisa kibr ü kîni kodunısa İkrâr bütün olmayınca erden nazar olmayısar

Son dizede dillendirilen ikrâr, yani söz verme 1st1lahını kısaca açmak faydalı olacaktır kanaatindeyiz. İkrâr, birinci olarak Allah’a "Elestu Bezminde" verilen söz (Kuran, 7: 172), ikinci olarak ta Yunus'un dervişi olduğunu bildiğimiz Bektaşilikte tarikata girişte ve musahip, yani yol kardeşi edinmede, bu yol kardeşine verilen söz demektir (Türk ve Çapar, 2011, s. $20 \mathrm{vd}$.). Yunus Allah’a ve kula verilen sözün birbirini bütünleyeceğini vurgular. Mutasavvıflar "Elestu Bezminde [Meclisinde]" Allah insanı ahitleşmeye değer bir muhatap, yani onu sözleşmenin tarafı kabul ederek onurlandırdığı düşüncesindedirler (İhvân-1 Safâ, 2013, s. 323). Kamil insanın yukarıda zikredilen iki manada da sözünü tutma cehdi onun tüm hayatını kapsar.

Yunus’a göre kamil insan, yani güzel erdemleri kendi sıfatı edinmiş insan kendisini çok yönlü ve hayat boyu olgunlaştıran insandır. Bu insanın ibadeti zaman ve mekanla sınırlı değildir, çünkü o zamanın her anında Allah ile olandır. Allah’a olan sevgi ve bağlılığı o kadar ileridir ki, onun ibadetinde kemiyet, mekan ve vakit mefhumu anlamını kaybeder, onun için zaman durmuştur. Bu zamanı ve mekanı aşma ve ona sığmama durumu, aynı zamanda her şeyi Allah karşında yok sayma (fenâ), kendi arzusunu Allah'in r1zasiyla bütünleștirme ve onda yok etme azmini ifade eder. Yunus der ki (Tatc1, 2005, s. 35 [20]):
'Işk îmâmdur bize gönül cemâ‘at

Kıblemüz dost yüzi dâimdür salât

Cân dost mihrâbına secdeye vardı

Yüz yire uruban ider münâcât

Biş vakt tertîbümüz bir vakte geldi

Biş bölük oluban kim kıla tâsat

Şerîat eydür bize şartı bırakma

Şart ol kişiyedür ider hıyânet

Yukardaki dizelerde ifadesini bulan kamil insanın dindarlığı ibadetleri şeklen ifa etmenin ötesinde sevgi ve samimiyetle yoğruluş ve hayatın her anında kendini Allah’in huzurunda hissediş, yani "ihsan" mertebesine (Cürcânî, 2014, s. 69) erişmişliktir. Bu anlamda Yunus sadece ibadetlere değil, onların ferdi ve toplumsal sonuçlarına atıfta bulunarak zımnen de olsa din ve değer eğitim ve öğretiminde kazanım merkezli bir yaklaşımının önemine vurgu yapar.

\section{İnsân-ı Kâmil Çerçevesinde Yunus Emre'nin Ahlak Anlayışı}

İnsân-1 Kâmil ahlaken bir rol model niteliğine ulaşmış şahsiyeti temsil eder. İnsân-1 Kâmil sürecinde önemli mesafe kat eden şahsiyet ahlaki davranışların temelindeki düşüncelerin, yani değerlerin taşıyıcısı ve koruyucusu konumuna ulaşan bir kişilik demektir. Sadece değerlerin amele dönüşmesinde değil, onların eğitiminde ve nesillere aktarımda da bu rol model kişiler birer öncü durumundadırlar. Değer ve ahlak eğitimi gibi bir ruh ve bilinç eğitiminde özellikle etkin olan şey, öğrenenin bu değeri taşıyıp onunla aynı şartları paylaşan ve kendisiyle duygusal iletişim kurabileceği örnek kişileri bilmesi ve görmesi ve hissedebilmesidir. Değerleri canlı kılan örnek kişilerin var olması, bu değerlerin yaşanabilir ve elle tutulabilir olduğunu, yani ütopik ve realiteden uzak olmadıklarını göstermesi bakımından toplum üzerinde oldukça etkilidir. Bu nedenle zamanını aşıp günümüze kadar tesiri ulaşmış bir toplum eğiticisi olan Yunus'un ahlak ve değer yaklaşımı konumuz bağlamında oldukça mühimdir. Bu yaklaşımın ana noktalarını kısaca şöyle özetleyebiliriz.

Bugünün dünyasında en önemli değer "başarı" ve "sahip olmak" olarak tezahür etmektedir. Başarı mutlaka ahlakî olmalıdır diye bir ilke de kendini fiiliyatta kabul ettirmiş gözükmemektedir. Bu da günümüzde ahlakın değerlerin mutlak kaynağı olarak görülmedi- 
ğine işaret eder. Yunus başarıyı ve elde etmeyi bir değer olarak önemsemekle beraber "terki" de bir değer olarak algilar ve der ki (Tatc1, 2005, s. 152 [152]:

\section{Ben nesneyi terk eyledüm, yürimege ázm eyledüm}

İnsanın onurundan insanın elde ettiklerini anlayan bugünkü modern düşüncenin aksine, Yunus insanın sahip olduklarının insana sahip olmaması gerektiğini vurgular ve refahın ile şanın insaniliği gasp etmesine razı olmaz. O der ki (Tatc1, 2005, s. 18):

\section{Her kim 'izzetden geçmedi âşsıllı bühtândur ana}

Yunus Emre'nin Risâletün-Nushiyye (2012) isimli eseri başlı başına bir ahlakî ve irfanî nasihatler kitabıdır. Yunus bu eserinde değerin ahlakla tenakuza düşmemesi gerektiğini defaten vurgular. Hukukun ve onun arkasındaki en önemli yazılmamış normları ifade eden değerlerin ahlakî olmama durumu ise bir anlamda değer erozyonu demektir. Jürgen Habermas modern ahlak ile modern hukukun birbirini tamamlayan öğeler olduğunu ifade ettikten sonra, şunu ekler ve der ki, hukuk ahlaklı olmak zorundadır fakat hiyerarşik olarak ahlakın altında değildir (Habermas, 1998: 137 vd.). Habermas'in burada tenakuza düştüğü şey, onun, ahlakın hukukun içine sindiğini ve hukukun genel prensiplerini güçlü bir şekilde belirlediğini söylemesine rağmen, ahlakın hukukun önüne geçmemesi gerektiğini belirtmesidir. Bu durumda akla gelen şey, hukukun gerektiğinde ahlakın tasvip etmediği şeyi hâkim kesimlerin menfaatlerini gözetmek amacıyla kanunlaştırabileceği tehlikesidir. Ahlak, akıl ve bilgi arasında mutlaka bir bağın olması gerektiği bu bağın bir yandan bilginin ahlakileşmesi (irfanileşmesi), diğer yandan da ahlakın bilgiye başvurması şeklinde belirgin hale geldiğini söyleyebiliriz. Mesela cenine veya insan genlerine bir müdahalenin nasıl olacağı ve hangi sonuçları doğuracağını bilmeyen bir ahlak, adı geçen bilimsel müdahaleyle ilgili etik ilkeleri vazedemez. Ahlakın akıl ve bilgiyle sürekli tenakuza düşmesi ve bunun insana ve insanileşmeye zarar verme boyutuna varması kabul edilemez bir durumdur. Bu duruma düşen bir ahlak kuralı, bir başka değimle bir değer kendini tashih etmek durumundadır. Neticede ahlak cumud bir olgu değil, dinamik olan ve eylemsellik boyutu bulunan bir düşünce olmak zorundadır.

Yunus Emre akıl, ahlak ve olgun iman arasında bir insicamın olduğuna kanidir. Aslında bu kanaat hemen hemen tüm İslam alimlerinin ortak kanaatidir diyebiliriz. İslam aklın peygamberliği kabule başlamasıyla ilahi vahyin insan eliyle, ki bu insan peygamberdir, insan aklına hitap ettiği gerçeğini esas alır. $\mathrm{Bu}$ noktadan itibaren akıl ve peygamberlik arasında bir iletişim kapısı açılır ve akıl vahyi akl etmeye başlar ki, vahiy de zaten insana hitap etmekle insan aklını muhatap almıştır. Akıl ve vahiy arasındaki bu iletişimi İmam Cafer en veciz bir şekilde şöyle ifade eder: "Allah ile insanlar arasındaki hüccet peygamberlerdir, insanlar ile Allah arasındaki hüccet ise akıldır." (Kuleyni, 2007, 13 [el-İlm ve-c-Cehl, Hadis No 22]). Kuranda Peygamber (s.a.s.) ahlak/değer kaynağı ("Muhakkak ki sen güzel bir ahlak üzeresin" [68: 4]) ve örnek al1nacak kişi ("Şüphesiz ki Allahin Resulünün şahsinda sizin için güzel bir örnek vardır" [33: 21]) olarak sunulur. Yunus'un Risâletü̈n-Nushiyye adlı eserinde akıl ve ahlak işbirliği oldukça vurgulanır. Bu akıl ahlakın kavranıp uygulanması, hikmetinin anlaşılmasına yardım eder ve insanın kötülüğ̈̈ emredici nefsin (egonun) etkisine girmemesi için bir uyarıcı görevi görür (Yunus Emre, 2012, s. 52-60).

İmanın ve ibadetin ahlakla bütünleşmesi sahibine erdem kazandırmasıyla tezahür eder. İnsanın ibadeti, onun hemcinsine ve tüm varllğa karşı muamelesinin ahlakileşmesiyle anlam, derinlik ve muteberlik kazanır. Bu nedenle İslam makasıd denilen dinin temel amaçlarını, insanın canını, malını, aklını, neslini ve dinini korumak şeklinde zikretmektedir. Din de dahil olmak üzere burada öncelikle korunması istenenler ya insana ait olan veya ona lazım olanlardır (Polat, 2010, 31 vd.).

Yunus bilmek (kendini, varlığı ve Allah’ı bilmek), akletmek, sevmek (tüm var olanı sevmek) ve erdemli olmak (varlığın onuruna uygum eylem yetisine sahip olmak) üçlüsünü birbirinden ayrılmaz görüp onlara sürekli vurgu yaparak evrensel ahlak ilkelerinin İslam'ın medeniyet lisanıyla ifadesine Anadolu'da öncülük etmiştir.

\section{Bir İnsân-ı Kâmil olan Yunus Emrenin Evrensel Bakış Acısı}

Kamil insan olma sürecinde belli mesafe elde eden kişilerin düşünce, duygu ve algı sınırları oldukça genişleyip evrensel bir karaktere ulaşır. Onlardaki düşünce sınırlarının genişlemesi yorumlarının daha zengin ve bakış acılarının daha kapsayıcı olmalarını da beraberinde getirir. $\mathrm{Bu}$ şahıslarda tekamül eden Yaratan ve 
yaratılan sevgisi onların ahlak anlayışının rahmetle bütünleşmesine ve neticede tüm varlığa aynı nazarla bakmalarına ve merhametle muamele etmelerine etki eder. Bu düşünce, duygu ve gönül dünyasındaki genişleme kamil bir insan olan Yunus Emre'de kendini belirgin bir şekilde hissettirir. Yunus İslam’ın mana ve medeniyet sınırlarının Müslümanların coğrafi ve zihinsel algı sınırlarına sığmadığını, bu nedenle onun tüm insanları kapsayacak, yani cihan şümul şekilde yorumlanması gerektiğini düşünür. Buna ilaveten o hitabının (öğretisinin) herkesin anlayacağı bir dil ve anlatım kolaylığına bürünmesini şiir yoluyla sağlayarak muhatap kitlesini (öğrenen kitlesini) geniş tutmayı başarmıştır. Yunus'un bu anlamdaki başarısı onu, tesiri günümüze kadar ulaşan bir halk eğiticisi konumuna yükseltmiştir.

Yunus'un erk sahiplerinin toplulukları kendine muti kılmak ve toplumsal hareket fikrini dizginleme saikine uygun olacak şekilde İslam fikhını yorumlamalarına ve yorumlatmalarına karşı çıkışı ilk anda aşır1 (heterodoks) bir tutum izlenimi oluştursa da, bu izlenim onun şiirlerinin içeriğine daha da derinden bakıldığında ortandan kalkar. Yunus'un bazı şiirlerindeki görünüșteki Allah’a serzenişi (bir nevi "şatah" da denilebilir [Cebecioğlu, 2014, 452 vd.]), aslında Allah’ın zatına değil, bilakis Allah’ın muradını iman (usul) ve amel boyutunda (füruğ) eksik anlayanlaradır. Yunus der ki (Tatcı, 2005, s. 401 [417].

\section{Terezü kurdun günâhum tartmaga}

Kasd idersin beni oda atmaga

Terâzû ana gerek bakkâl ola

Ya bazirgân tâcir ü 'attâr ola

Yukarıda okuduklarımız sevenin "Sevgiliye" bağl1l1ğından doğan bir içini dökme gibi anlaşılsa da, daha çok Yunus'un ulemaya (din alimlerine) bir ihtarıdır. Sözün sahibini (Allah’̉) bilmeden onun sözünü (Kuranı) anlamanın çok zor olduğunu düşünen Yunus, ilimle imanı bir tutar. O imanın kademlerini anlatırken kendinden önceki ve sonrakilerin ilmin kademelerini anlatmak için kullandıkları sstılahları kullanır ve böylelikle ilim ve iman arasındaki derin ilişkiye dikkat çeker. Yunus iman üç türlüdür diyerek şunlar1 siralar (Yunus Emre, 2012, s. 9): 'İlmel yakîn, bu ilim akılda yerleşiktir, diğeri 'ayn’el yakîn' ki bunun da mekanı (kaynağı) gönüldür ve üçüncüsü ise, hakk’elyakîn'dir ve bu canda (ruhta) yerleşiktir.
Yunus İslam’ı bir inanç ve yaşam şekli olarak özgürleştirici bir yapı olarak görür. Aklı ve yaşamı özgürleştiren ve Yaratıcının dışında kimseye bağımlı olmamayı öğütleyen bu görüş Allah’ın azabından emin olmak için onun Rahmetinden emin olmak gerektiğine vurgu yapar. Yunus Emre der ki (Tatc1, 2005, s. 400 [417]):

\section{Kıl gibi köpri yaparsin geç diyü Geçüben kevser şarâbın iç diyü Kıl gibi Sırâtıdan Âdem mi geçer Yâ üzilür yâ tayanur ya uçar Yine fazlundur kulunı geçüren Geçüben kevser şarâbın içüren}

\section{Yunus Emre Düşüncesinde Bir Değer olarak "Aşk" ve Bir "Aşık" Olarak İnsân-ı Kamil}

Yunus Emre insanı ayrıt etmeden sevgiyi paylaşarak çoğaltmanın inanca ve değerlere duygusal derinlik ve içtenlik katmak olduğunu ifade eder. O maneviyat ve karakter eğitimi anlamına da gelen ibadetin insanda erdemli hal ve eylem olarak görünmesini, malumatın ilme, ilmin ise hikmete yükselmesini bekler. Sevgi bilginin ahlakileşmesi, Yunus'un deyimiyle helal hale gelmesi, yani irfana dönüşmesi için temel değer mesabesindedir (Yağmur, 2013, s. 41).

\section{İlm ü amel zühd ü taat bes aşksız helal olmaya}

Yunus Allah ve tüm varlığa olan sevgiyi "aşk" olarak ifade eder. Çünkü aşk sevgiden ötedir; aşk bağlanmayı eyleme ve tutku haline getirmeyi, gerektiğinde kendini feda edebilmeyi ifade eder. Yunus her şeyde haddini bilir, had tanımadığı tek değer ise aşktır. Hem Yaratanla ve yaratılan arasındaki, hem de yaratılanların kendi arasındaki ilişkinin mihengi, yani ana değeri aşktır ona göre. Aşk, Allah ile kamil insan arasındaki dünyevi ve cismani arzuya dayanmayan sevgi, hürmet ve güvene dayalı bağlanmanın adıdır. İslam Kültüründe bu bağlanmanın en üst düzeyde örnekleri vardır, mesela Hz. Muhammed'e (s.a.s.) habibullah, yani Allah’n sevdiği, Hz. İbrahim'e (a.s.) ise halilullah, yani Allah'in dostu unvanı ile anılırlar.

Yunus Emre İnsân-1 Kâmil sürecine giren şahsın Allah’ı ve kendini bilme boyutuna aşk boyutunu da 
katmasını elzem görür. O insanın Allah’tan korkarak Ona teslim olma konumunu daha da ileri götürerek Ona aşkla bağlı olma seviyesine çıkarmasını inanç eğitiminin bir üst aşaması olarak telaki eder. Bu manda Yunus der ki (Yağmur, 2013, s. 41):

Aşk eteğin tutmak gerek âkıbet zeval olmaya Așktan okusan bir elif kimseden sual olmaya

Aşk aslında Peygamber Efendimizin Cibril hadisinde ifadesini bulan "ihsân" mertebesine işaret eder (Buhari, iman, bab 36, Hadith-No 50; Muslim, iman, 1). İhsan her şeyi bizzat Allah’ı görür gibi yapmaktır. Bu manada aşk kendisinden hiçbir şey gizlenemeyen "Maşukun" gönlünü kırmama korkusunu, yani havf' $\mathrm{i}$ de içerir. Yunus der ki (Yunus Emre, 2012, s. 18):

Aya uslu kişi sen bir haber vir

Nerede var bize ger gizlenecek yir

"Sevgilinin", yani "Maşukun" sevgisini kaybetme korkusu (havf) "Sevgilinin" dışında her şeye meydan okuyabilme cesaretini verir, bu anlamda bu "korku" özgürleştiren bir korkudur. Yunus'ta "aşk" ve "havf" birbiriyle iç içe olup her ikisi de özgürleştiricidir. Kark Jaspers’in dediği gibi asıl olan insanın özgür iradesiyle kendini "Aşkın Varlığın" bir lütfu olarak görmesidir. Bunun neticesinde insan kendi özgürlügünü "Așkın (müteal) Varlığın” emrine amade kılarak, bu özgürlüğün "Aşkın" olanın iradesiyle birleşmesine imkan sunar (Jaspers, 2012, s. 57). Bu meyanda Yunus kendi iradesini Allah'in rizasiyla birebir uyumlu hale getiren kişinin mükafat ve azap sorusunu aşmış ve emniyet içinde olduğunu ifade eder. "Mümin" kelimesi ile "emniyet" kelimesinin Arapçada aynı kökten türediğini bu arada hatırlatmak isteriz. Yunus'un aşağıdaki dizelerini yukarda zikredilen bağlamda tefsir etmemiz mümkündür kanaatindeyiz (Tatc1, 2005, s. 32 [17]):

Tâ‘at kılan uçmagıçün dîn tutmayan Tamu içün Ol ikiden fârig olur neye benzer bu işâret Her kim dostı severise dostdan yana gitmek gerek İşi güci dost olıcak cümle işden olur âzât Anun gibi ma`şûkanun haberini kim getürür Cebrâill-i mürsel sıgmaz anda olıcak münâcât Sorı hisâb olmayısar dünyâ âhiret koyana Münker ü Nekir ne sorar terk olıcak cümle murâd
Havf ü recâ nice gelür varlık yokluk biragana İlm ü 'amel sıgmaz anda ne terâzû ne hod sırat Ol kıyâmet bâzârında her bir kula baş kayısı Yûnus sen âşıklarıla hîç görmeyesin kıyâmet

Yunus Emre düşüncesin ana iksiri aşktır. O, aşkı kamil insanın kamil imanı olarak görür, ki bu aşk şehvet ve beklenti asla ve asla içermez. Yunus "İ 'âşıkan iy âşıkan 'ş̧k mezhebi dindür bana" (Tatc1, 2005, s. 24 [7]) der ve ekler (Tatc1, 2005, s. 398 [416]):

Nâgâh yagmâ eyledi 'ş̧k odı cânumuzı

Hîç kimse nitelikden virmez nişânumuzı

Ne îmâna bakdurur ne hod dîne tapdurur

'Iş̧ odı şöyle dutdı yıkdı dükkânumuzı

Virdi birlikden şarâb kılduk dükkânı harâb

Cümlesini terk itdük assı-ziyânumuzı

Niçe nişân vireler kangı yoldan soralar

Kamusin elden koduk dîn ü îmânumuzı

Ne assı var ne ziyân gelsün cânuna kiyan

Cümlesinden geçüben bulduk Sultânumuzı

Birlikdedür varumuz biz bir olduk kamumuz

İkilik söylemege komaz lisânumuzı

\section{Ortaöğretim Felsefe Dersi Öğretim Programına Yunus Emre Düşüncesi Bağlamında Bir Bakış}

Değer öğretilir bir olgudur ve bu nedenledir ki değer eğitiminden çok öğretiminden bahsetmemiz gerekir kanaatindeyiz. Değerin insana öğretilmesi öncelikle o değerin kaynağın $ı n$ - bu kaynak din olabilir, kültür olabilir, tarih olabilir - bilinmesiyle mümkündür. Bu bilinme okul öğretim programlarında nelerin öğretilmesinin planlandığı ve bu öğretilenle kişiye ne gibi bilgi, beceri ve kabiliyetlerin (competence) kazand1rılmasın hedeflediğiyle yakından ilgilidir.

Anadolu İslam coğrafyasında Değer Felsefesinin (Aksiyoloji) mümeyyiz simalarından biri olan Yunus Emre’nin öncelikle değer, insan, bilgi ve eğitim felsefesi alanlarına girebilecek görüşlerini ders konusu olarak dikkate alması gereken en önemli derslerden biri Ortaöğretim müfredatında yerini bulan Felsefe Dersidir. Bu sebeple Felsefe Dersi Öğretim Programın Yunus Emre'nin görüşleri muvacehesinde hem öğretim bilimi (didaktik) ve hem de içerik yönünden bir 
analize tabi tutmayı önemli bulmaktayız. Bu analizin günümüz okul eğitim ve öğretiminde medeniyet coğrafyamızın en önemli düşünce ve maneviyat önderlerine ne kadar ve nasıl yer verdiğimizi tespite küçük te olsa bir katkı sunabileceği ümidindeyiz. Felsefe Dersi Öğretim Programı temel yaklaşımlarını şöyle sıralamaktadır (Milli Eğitim Bakanlığı Ortaöğretim Genel Müdürlüğ̈̈, 2009, s. 5-6):

1. "Her öğrencinin birey olarak kendine özgü olduğunu kabul eder. Bireysel farklılıklara saygıyı ön planda bulundurur.

2. Aktif öğrenme metotlarını temel prensip olarak kabul eder.

3. Eğitimin sosyalleştirme işlevinden hareketle; bireyleri birlikte çalışmaya, fikir alışverişi yapmaya ve soru sormaya özendirir.

4. Millî eğitimimizin amaçları doğrultusunda millî değerleri koruyup geliştiren, evrensel değerleri benimseyen bireylerin yetiştirilmesine vurgu yapar.

5. Öğrencilerin; özgür düşünebilen, sorumluklarının farkına varan, haklarını bilen, çevresiyle uyumlu kişiler olarak yetişmeleri için çaba gösterir.

6. Bireylerin demokrasi içerisinde hakları olduğu kadar görevlerinin de olduğunu kabul eder.

7. Kültürel ve sanatsal değerlerimizi, kişilik gelişiminin ve toplumsallaşmanın bir aracı olarak görür.

8. Öğrencilerin kendini, dünyayı ve evreni felsefe aracılığı ile sorgulamalarını hedefler."

Yukardaki maddelere baktığımızda 2. maddenin dersin öğretim yaklaşımını açıkladığını diğerlerinin ise derste elde edilmesi istenilen üst (meta) eğitim ve öğretim hedeflerini sıraladı̆̆ını görürüz. Bu hedeflerin bir kısmının farklı olana saygı (1.), birlikte çalışma (3.), özgürlük ve sorumluluk gibi değerlere atıf yaptığını gözlenmektedir. Adı geçen programın Ahlak Felsefesi isimli 4. Ünitesinde yer bulan İnsanın Sorumluluğu konusunun kazanımlarından biri olan 9. kazanım "Evrensel bir ahlaki tavır olarak Anadolu bilgeliğinin başlıca örneklerini tanır" şeklinde ifade edilmektedir
(Milli Eğitim Bakanlığ Ortaöğretim Genel Müdürlügü̈, 2009, s. 31). Bu kazanım dan hareketle ve yukarıda anılan 1. hedefte ifade edilen farklı olana saygı vurgusu da dikkate alınarak Yunus Emre'nin evrensel ahlak çerçevesinde değerlendirilebilecek görüşlerini derste konu edinme imkanı bulunmaktadır. Fakat Yunus'un varlık, insan, eğitim ve din felsefesine raci görüşlerine de yer verme lüzumu bu programda belirgin olarak ifade edilmediğinden, ögrretmenin kendiliğinden bu hususları derste işleme ihtimali oldukça zayıftır. Yukarda adı geçen 9. kazanım ile ilgili olarak yapılan açıklamada, "Ahmed Yesevi’nin, Mevlana’nın, Yunus Emre'nin, Hacı Bektaş-1 Veli’nin sevgi temelli ve evrensel kucaklayıcıllğ 1 olan görüşlerinden örnekler verilmelidir" denilerek bu düşünürlerin fikirlerinin sadece bir boyutuna programda işaret edilmektedir (Milli Eğitim Bakanlı̆̆ 1 Ortaöğretim Genel Müdürlügü̈, 2009, s. 31). Bu fikirlerin ilim, akıl, inanç ve amel boyutuna ise hiç dikkat çekilmemektedir.

Ortaöğretim Felsefe Dersi Programında işlenmesi öngörülen Ahmed Yesevi, Mevlana, Yunus Emre ve Hacı Bektaş Veli’nin görüşlerinin ilgili dersin Milli Eğitim Bakanlığınca onaylanmış ders kitabına yansımasını tartışmayı adı gecen dersin öğretim programının tahlilini tamamlayıcı nitelikte olduğu için önemsemekteyiz. Ortaöğretim Felsefe Ders Kitabının 4. Ünitesi Ahlak Felsefesini konu edinir. Bu ünitenin alt konularından birisi de "Anadolu Bilgeliği ve Evrensel Ahlak Yasası" konusudur (Karavelioğulları, 2015, s. 123-125). Bu konu başlığı altında Ahmet Yesevi’nin, Mevlana’nın, Yunus Emre'nin ve Hacı Bektaş Veli'nin ilgili görüşlerine kısaca da olsa değinilmiştir. Fakat bu ders kitabı da ilgili dersin programında olduğu gibi ne Yunus'un ne de adı geçen diğer şahısların varlık, bilgi ve eğitim felsefesine ait düşüncelerine yer vermemiştir.

Lise Felsefe Dersi Programlarındaki konuların ve düşünürlerin seçiminde Batı düşüncesine ağırlık verildiği net bir şekilde görülmektedir. Halbuki ders programları bir yandan diğer medeniyetlerin akli üretimine yer verirken, diğer yandan da muhatap aldığ toplumun kendine has düşüncelerini tanımak ve onları güncel bakış açısıyla tartışmaya tabi tutmak durumundadır. Sadece başkalarının fikri üretimlerini tekrar etmek fikri tüketicilik anlamına gelir ve öğrencilerin tüm hayatlarında da tüketici ve taklit edici yaklaşımı benimsemelerine etki eder. Bir ülkenin felsefe, eğitim ve kültür dünyasının önemli fikirlerinin ve bu fikirlerin 
taşıyıcısı olan şahsiyetlerinin o ülkede akli yaklaşımları ve fikri akımları konu edinen Felsefe Dersinin programına yeterince yansımaması o ülkede kendine yabancılașmanın ileri bir safhada olduğunun göstergesidir. Okul bilimsel disiplinlerin kendine özgü araştırma ve geliştirme metot ve materyalleriyle elde ettiği en son ve en güvenilir bilgileri ilgi ve ihtiyaca göre öğretmeyi ödev edinir. O buna ilaveten halkın değerlerinin, bilgi, beceri ve kabiliyet birikiminin gelecek nesillere aktarılmasına ve onları sadece sahiplenici bir tavırla değil aynı zamanda tenkide de tabi tutarak onların bilimsel gelişimine ve kavranmasına da hizmet etmek durumundadır. Bu anlamda okullardaki öğretim hedef kitlenin mazisinde bugününde ve istikbalinde mevcut olan ve olması gereken maddi ve manevi kazanımları öğrenenler için ulaşılabilir, tartışlabilir ve anlaşabilir hale getirmenin de bir adıdır. Az öncede zikredildiği gibi okul gerektiğinde muhatap aldığı toplumun kültür ve düşünce mirasını bilimsel bir eleştiriye tabi tutar ama onu yok sayamaz, aksi durum toplumu evrensel bağlamda hakim kültür ve düşüncelerin bir kolonisi haline dönüştürür ve kendine özgün üretim yapmasının önünü tıkar. Kültürün bir nesebi ve bilginin bir gelişim süreci vardır, bunlar öğretim programlarında dikkate alınmalıdır.

Günümüzde vazedilen eğitim ve öğretim kazanımları bu günün yetiştirilmek istenilen insanının nasıl tasavvur edildiğine 1 şı tutmaktadır. $\mathrm{Bu}$ tasavvur kendini üretken, sorumluluk alan, bilgili, iş ahlakına sahip, ortak ve uyumlu çalışabilen, sorun çözme ve yönetme kabiliyetine sahip, esnek hareket edebilen ve yeni şeylere açık insan yetiştirmek şeklinde açıklar. İslam medeniyet dünyası geçmişte mümkün olduğu kadar en iyi vasıfları kabiliyetleri ölçüsünce kendinde toplama sürecine giren insanı İnsân-1 Kâmil olarak tarif edip bu insanı yetiştirmeyi hedeflemiştir. İnsân-1 Kâmil kavramı aynı zamanda Kuran'da ifadesini bulan "Allah’ın yeryüzündeki halifesi olan insan" (Kuran, 2: 30 vd.) sifatlamasıyla da yakından ilintilidir. Burada asli soru şudur: Acaba kültür ve medeniyet dünyamızın en önemli eğitim ve öğretim kavramı olan İnsan-1 Kamil kavramı ülkemizdeki öğretim programlarına bir nebze de olsa yansımış mıdır veya en azından bu kavrama programlar çerçevesinde değinilmiş midir? Bu makalede bu soruya Yunus Emre’nin İnsan-1 Kamil düşüncesi özelinde ve ortaöğretim Felsefe Ders Programı örneğinde cevap aranmış olup sonuçta elde edilen netice İnsan-1 Kamil eğitim tasavvurunun programlara ve ilgili ders kitaplarına yeterince yansitılmadığ 1 şeklindedir. Mevlana, Hacı Bektaş Veli ve Yunus Emre gibi Anadolu İslam Coğrafyasının önemli şahsiyetlerince de benimsenen İnsân-1 Kâmil eğitim tasavvurunun hem bilgi (epistemolojik), hem insan (antropolojik) ve hem de varlık felsefesi (ontolojik) boyutları vardır ve bu haliyle tekmil bir eğitim ve öğretim modeli olarak tanımlanabilir. Ayrıca bu modelin günümüz eğitim yaklaşımlarıyla da bazı örtüşen tarafları mevcuttur diyebiliriz. Örneğin Batıdan alınan ve günümüzde revaçta olan "öğrenci merkezli öğretimin“ daha da kapsamlı şekli Yunus Emre’nin insan merkezli tasavvuf düşüncesinde kendini hissettirir. Eğer Yunus'un eğitim ve öğretim düşüncesi yeterince araştırılabilseydi bunun farkına varılır ve bizim kültürümüze uygun ve özgün bir "insan merkezli öğretim" düşüncesinin kültürel altyapısı keşfedilirdi. Yine günümüzde oldukça kabul gören kazanım merkezli (competence oriented) öğretim yaklaşımı Yunus'un düşüncesinde kısmen ifadesini bulur. Onun aşağıdaki beyitleri bilgi merkezli eğitimin yanında kabiliyet ve değer merkezli eğitimi vurgular niteliktedir. Yunus kendini bilmeyi bir kabiliyet (competence) olarak görür ve bunu öğretimin en önemli kazanımı olarak tarif eder (Tatc1, 2005, s. 101 [91]):

\section{'İlim 'ilim bilmekdür, ilim kendin bilmekdür.}

Sen kendüni bilmezsin, yâ nice okumaktır

\section{Sonuç ve Değerlendirme}

Eğitim ve öğretim bir yandan bilimin ulaşmış olduğu yeni kazanımlara ve evrensel doğrulara atıf yaparken diğer yandan da muhatap aldığı toplumun tarihi, kültürel ve düşünce mirasına önem vermek durumundadır. Her toplumun ortak hafızasında, bilinç altında ve nihayet eğitim siyasetinde kaleme dökülen veya dökülmeyen hedefleri bulunmaktadır. Bu hedefin bizim medeniyet dünyamızdaki karşılığı olan "İnsân-1 Kâmil" yetkin ve olgun insana ve bu insandan hareketle de erdemli topluma yürümeyi ifade eder.

Kamil insanın her yüzyılda portresi değişir. Örneğin 10. yüzyılın kamil insan tasviriyle 21. yüzyıldaki kamil insan tasviri aynı değildir. Değişmeyen şey ise bu insanın bilgili, akıllı, ahlaklı ve üretken olması hedefidir. Akıllı olmak, ahlaklı olmak ve üretken olmak nasıl olmadır sorusuna her ülke, içinde yaşadığı mahalli ve küresel şartları da dikkate alarak kendi öz cevabını vermek durumundadır. Bu cevap aynı zamanda ülkenin eğitim ve öğretim hedeflerini tarif etme anlamına 
gelir. Kısaca dillendirilen bu bakış acısıyla bu makalede örnek olarak analiz etmeye çalıştığımız "Felsefe Dersi Öğretim Programı” ve bu programın tezahürü olan "Ortaöğretim Felsefe Ders Kitabı" Yunus Emre gibi Anadolu İslam Düşüncesinin önemli bir şahsiyetinin görüşlerine hem nicelik hem de nitelik olarak yeterince yer vermediği sonucudur. Bu program ve ilgili ders kitabında sadece Yunus Emre değil, genel olarak İslam Felsefesinin ve Tasavvufunun diğer temsilcileri de yeterince yer bulamamışlardır. Örneğin ilgili programda Fârâbi’nin ismi Devlet Felsefesiyle ilgili olarak bir kez geçmekte (Milli Eğitim Bakanlığı Ortaöğretim Genel Müdürlüğü, 2009, s. 34), Gazzali, İbni Sina, İbni Rüşd gibi önemli düşünürlerin adı hiç anılmamaktadır. Ahmet Yesevi, Yunus Emre, Mevlana ve Hacı Bektaş Veli isimleri ise adı geçen bu programda Ahlak Felsefesi bağlamında kısaca dile getirilmektedir (Milli Eğitim Bakanlığı Ortaöğretim Genel Müdürlüğü, 2009, s. 31). Anadolu İslam Düşüncesinin tasavvuf önderleri ve aynı zamanda halk eğiticileri olan bu şahsiyetlerin görüşlerine Ortaöğretim Felsefe Ders Kitabında çok yüzeysel ve kısa değinilmektedir. Toplam 222 sahifeyi bulan bu ders kitabında adı geçen şahısların biyografileri ve görüsslerine beş adet resim ve bir alıştırma da dahil olmak üzere toplam 3 sayfa ayrılmıştır (Karavelioğulları, 2015, s. 123-125).

İslam medeniyetinin insanı öğretme ve eğitme düşüncesini, iddiasını ve idealini özgün bir şekilde tarif eden İnsân-1 Kâmil tasavvuru kendi içinde değişimi ve terakkiyi besleyen dinamik bir modeldir. Bu model bir nihai oluş noktasını değil, bir ahlaklanma, bilgeleşme ve ilmiyle âmil olma sürecini ifade eder. $\mathrm{Bu}$ tasavvurun inanç boyutunu Yunus kısaca Allaha olan aşk şeklinde dillendirir, antropolojik boyutunu ise Yunus'un insanı Allah'in sıfatllarının tezahürlerinin seyredildiği ayna olarak görmesini şeklinde özetleyebiliriz. İnsân-1 Kâmil tasavvurunun bilgi boyutunu ise Yunus Emre (diğer bir çok mutasavvifta olduğu gibi) ilm’el yakîn (okuyarak öğrenme ve bilme), ayn’el-yakîn (görerek ve yaşayarak öğrenme ve bilme) ve hakkel-yakîn (bilginin hakikatinin sırrına ererek, o hakikatle bir olarak ve özdeşleşerek öğrenme ve bilme) şeklinde tasnif ederek açılar. Yunus ayrıca bilginin ahlakileşmesini ve içselleştirilmesini, yani irfana ve hikmete dönüşmesini ve sahibini de erdemli davranışa götürmesini ister. O bilgiyi bir başka deyimle ilmi sadece yapabilmek, sahip ve hakim olabilmek için değil sevebilmek, anlayabilmek ve tanıyabilmek için de önemser ve bilginin başlangıcını "kendini bilmek" olarak tarif eder.

\section{Kaynakca}

Buhari, Muhammed İbn 'İsmail. Ec-Cami’ es-Sahih.

Cebecioğlu, Ethem (2014). Tasavvuf Terimleri ve Deyimleri Sözlü̈̆̈̈ (6. Baskı). Ankara: Otto.

Cürcânî, Seyyid Şerîf (el-Cürcani, Ali İbn Muhammed) (2014). Tárîfât. Tasavvuf Istılahları. [Arapça ve Türkçe Tercüme birlikte basım]), Tolun, Abdulaziz Mecdi (Terc.), Acer, Abdulrahman (Ed.), İstanbul: Litera Yayıncilı.

Çetin, Osman (1981). Selçuklu Müesseseleri ve Anadolu'da İslâmiyet'in Yayılışı. İstanbul: Marifet.

Eraslan, Kemal (2016). Yesevînin Fakr-nâmesi. Ankara : Hoca Ahmet Yesevi Uluslararası Türk-Kazak Üniversitesi.

Farabi (el-Farabi, Ebu Nasr Muhammad) (2001). ElMedinetü'l Fâzila (Mabādi' àrä' ahl al-madina alfädila). Danışman, Nafiz (Terc.), Akara: M.E.B.

Gordlevski, V. (1988). Anadolu Selçuklu Devleti. Yaran, Azer (Terc.), Akara: Onur Yayınları.

Habermas, Jürgen (1998). Faktizität und Geltung. Beiträge zur Diskurstheorie des Rechts und des demokratischen Rechtsstaats. Frankfurt a. M.: Suhrkamp.

Halman, Talât Sait (1991). Yunus Emren'in Hümanizması. Özbay, Hüseyin ve Tatçı, Mustafa (Ed.). Yunus Emre ile İlgili Makalelerden Seçmeler (s. 161169). Ankara: Kültür Bakanlığı.

Hünkâr Hacı Bektâş-1 Velî (2007). Makâlât (Osmanl1ca ve Yeni Türkçe metin birlikte). Yılmaz, Ali; Akkuş, Mehmet ve Öztürk, Ali (Ed.), Ankara: Diyanet İşleri Vakfı Yayınları.

İbni 'anbel, Ebu Abdullah Ahmed İbn Muhammed. ElMüsned.

İhvân-1 Safâ (2013). İhvân-ı Safâ Risâleleri (Rasāỉ Ihwān as-safä wa-Hullān al-Wafā). Kahraman, Abdullah (Ed.); Çalışkan, İbrahim vd. (Terc.), Bd. 2, Istanbul: Ayrintı. 
İmam Gazali (el-Gazzali, Ebu Hamid Muhammed İbn Muhammed) (2004). Müminler İçin Yükselme Basamakları. Duran, Abdulhalık (Ed.), İstanbul: Hikmet Yayınevi.

Jaspers, Karl (2012). Der philosophische Glaube. München ve Zürich: Piper.

Kant, Immanuel (1786). Grundlegung zur Metaphysik der Sitten. (2. Baskı). Riga: Hartknoch.

Karavelioğulları, Neriman (2015). Ortaöğretim Felsefe Ders Kitabı. Ankara: S. E. K. Yayınları.

Kuleyni, Ebu Cafer Muhammad İbn Yaqub İbn Ishak (2007). Usul al-Kafî. Beirut: Manşurat al-Fecr.

Mevlâna Celâleddin Rûmî (2011). Mesnevî -Tam Metin - (8. Baskı). Konya: Palet.

Milli Eğitim Bakanlığı Ortaöğretim Genel Müdürlüğü (Ed.) (2009). Felsefe Dersi Öğretim Programı. Ankara: M.E.B.

Muslim İbn Haccac. Al-Cami es-Sahih.

Nesefi, Azizuddin (Necm'ed-Din Ebu Hafs Ömer İbn Muhammed) (2013). Tasavvufta İnsan Meselesi. İnsan-ı Kâmil (2. Baskı). Kanar, Mehmet (Terc.), İstanbul: Dergah Yayınları.
Nietzsche, Friedrich (2012). Gesammelte Werke. Köln: Anaconda.

Platon (tarihsiz). Der Staat. München: Wilhelm Goldmann.

Polat, Mizrap (2010). Frieden im Koran und seine religionspädagogischen Implikationen. Eine koranexegetische und fachdidaktische Betrachtung. Frankfurt a.M. vd.: Peter Lang.

Şeker, Mehmet (2002). Anadoluda Bir Arada Yaşama Tecrübesi: Türkiye Selçukluları ve Osmanlilar'da Muslim-Gayr-i Muslim İlişkileri. Ankara: Diyanet İşleri Başkanlığı.

Tatc1, Mustafa (2005). Yunûs Emre Dîvânı. Tenkitli Metin (2. Baskı). İstabul: M.E.B.

Türk, Hüseyin ve Çapar, Mustafa (2011). Alevilikte Yola Giriş Geleneklerinin Karşılaştırmalı olarak İncelenmesi. Türk Kültürü ve Hacı Bektaş Veli Araşttrma Dergisi, Say1 2011, Cilt 60, s. 17-42.

Yağmur, Sinan (Haz.) (2013). Yunus Emre Divanı. İstanbul: Dergah.

Yunus Emre (2012). Risâletü’n-Nushiyye. Boz, Erdoğan (Haz.), Ankara: Gazi Yayınları. 